Article

\title{
Depositional Architecture and Facies of a Complete Reef Complex Succession: A Case Study of the Permian Jiantianba Reefs, Western Hubei, South China
}

\author{
Beichen Chen ${ }^{1,2}$, Xinong Xie ${ }^{1, * \mathbb{C}}$, Ihsan S. Al-Aasm ${ }^{2}$, Feng Wu ${ }^{1}$ and Mo Zhou ${ }^{1}$ \\ 1 College of Marine Science and Technology, China University of Geosciences (Wuhan), Wuhan 430074, China; \\ polaristar@foxmail.com (B.C.); finncug@hotmail.com (F.W.); zhoumo.jasmine@foxmail.com (M.Z.) \\ 2 Department of Earth and Environmental Sciences, University of Windsor, 401 Sunset Avenue, Windsor, \\ ON N9B 3P4, Canada; alaasm@uwindsor.ca \\ * Correspondence: xnxie@cug.edu.cn; +86-6788-6160
}

Received: 26 September 2018; Accepted: 13 November 2018; Published: 16 November 2018

\begin{abstract}
The Upper Permian Changhsingian Jiantissanba reef complex is a well-known platform marginal reef, located in the western Hubei Province, China. Based on field observations and lithological analysis of the entire exposed reef complex, 12 reef facies have been distinguished according to their sedimentary components and growth fabrics. Each of the lithofacies is associated with a specific marine environment. Vertically traceable stratal patterns reveal 4 types of the lithologic associations of the Jiantianba reef: (1) heterozoan reef core association: developed in the deep marginal platform with muddy composition; (2) photozoan reef core association developed within the photic zone; (3) tide-controlled reef crest association with tidal-dominated characteristic of lithofacies in the shallow water; and (4) reef-bank association dominated by bioclastic components. The entire reef complex shows a complete reef succession revealing a function of the wave-resistant and morphological units. This study displays a complete sedimentary succession of Jiantianba reef, which provides a more accurate and comprehensive description of the reef lithofacies and a better understanding of the structure and composition of organic reefs.
\end{abstract}

Keywords: reef; reefal sequence; lithofacies; heterozoan carbonate; photozoan carbonate; Changhsingian

\section{Introduction}

Robert Riding [1] defines the reef as "essentially in place calcareous deposits created by sessile organisms", suggesting that reefs can be categorized as agglutinated microbial reefs, cluster reefs, segment reefs, frame reefs, cement reefs, non-skeletal cement reefs, and carbonate mud mounds. Concerning the reef frameworks and their growth pattern, the scheme introduced by Insalaco [2] proposed the concepts of superstratal and constratal growth fabrics and stated that such growth fabrics must be accurately identified within a reef facies. In a superstratal growth fabric, the constituent organisms grow higher than sedimentary substratum, creating positive topographic relief. In contrast, constratal growth occurs when constituent organisms grow at a rate similar to that of sediment accumulation. The environmental realm of carbonate depositional association introduced by James [3], which proposed the concepts of photozoan and heterozoan associations. The subsequent research also supports that the former better reflects shallow, warm-water, benthic calcareous communities, and their resultant sediments, while the latter is more inclined toward cold-water benthic communities and their resultant sediments beneath the photic zone [4,5]. At present, an increasing number of researchers have focused on the oceanographic controlling factors of the development of carbonate reefs, including temperature and nutrients [6,7], early marine cementation $[8,9]$, upwelling and non-upwelling environment [10], and pushed the study of reefs to a new climax. 
The Late Permian Changhsingian reefs are widely distributed around the Sichuan basin [11]. Sponges were the main skeleton builder of the reef in the worldwide during the Permian period [12-15]. The Jiantianba sponge reef complex, as the one of the typical marginal platform reefs, is located in western Hubei Province, South China. Fan [16] reported that the Jiantianba reef contain five different microfacies, including the deep basin, slope, reef front, reef core and back-reef lagoon. Fan \& Zhang [12] identified the essential features and dominant reef builders of the Jiantianba reef. Subsequently, Guo \& Riding [17] recognized the different types of microbial micritic fabrics of the Jiantianba reef and indicated that microbial micrites playing a cementing role formed coevally with the reef within the upper part of the photic zone. Liu \& Rigby [18] analyzed the diagenesis of the Jiantianba reef and identified different fibrous calcites, including isopachous fine-textured calcite, radiaxial calcite, and bladed calcite, all of which were interpreted to be of marine origin. Hu [19] recognized the four subsequences of the Jiantianba reef, for which a growth model was consequently provided.

These studies above are based on relatively scattered samples and the outcrop profile wrapped by soil and vegetation. Fortunately, due to the recent activities of the quarry, the complete reef complex was slabbed and exposed as the plane profile. With a length of 100-150 m and a height of about 50-80 $\mathrm{m}$, the plane outcrop of the reef body reveals the complete reefal sequence from the open platform to the reef cap deposits, which provides very favorable conditions not only for the study of the Late Permian carbonate platform marginal reef, but also a precise reef case for comparative study worldwide. Although, previous researchers employed many classic classification schemes for reef lithologies and presented very convincing categories for various types of reefs; however, to obtain a precise understanding of the corresponding reefal facies and determine the direct link between the facies types and marine sedimentary environments, the mechanisms through which different reefal facies coalesce to form a reef complex must be further explored. The objectives of this study are: (1) further recognize all lithofacies based on the excellent exposure of the reef complex in quarry profile, (2) explain the characteristic of lithofacies associations between the heterozoan reef core association, photozoan reef core association, wave-control reef crest association and reef-bank association; and (3) build a dynamic growth model of Jiantianba reef complex, which can be applied elsewhere in quantifying reefal facies.

\section{Geological Setting and Methods}

During the Late Permian, western Hubei-eastern Sichuan area was located in the central area of the middle and upper Yangtze region (Figure 1), which belongs to tropical environment during the Permian period [20,21]. Due to regional sea level rise, most of the eastern Sichuan-western Hubei area was dominated by open platform deposits. The water depths of the depositional facies within the Changhsingian Formation show shallowing upward cycles. In the lower part of the formation, deep basin facies are characterized by thick, black shale layers rich in organic matter. In the middle part, slope facies exhibit thick shale layers interbedded with thin carbonate beds. On top, a set of open platform sediments are deposited and the Jiantianba reef developed above it. This research focuses on constructing a complete reef profile that is approximately $120 \mathrm{~m}$ thick. Synthesis of columnar sections of the reef profile are shown in Figure 2. 


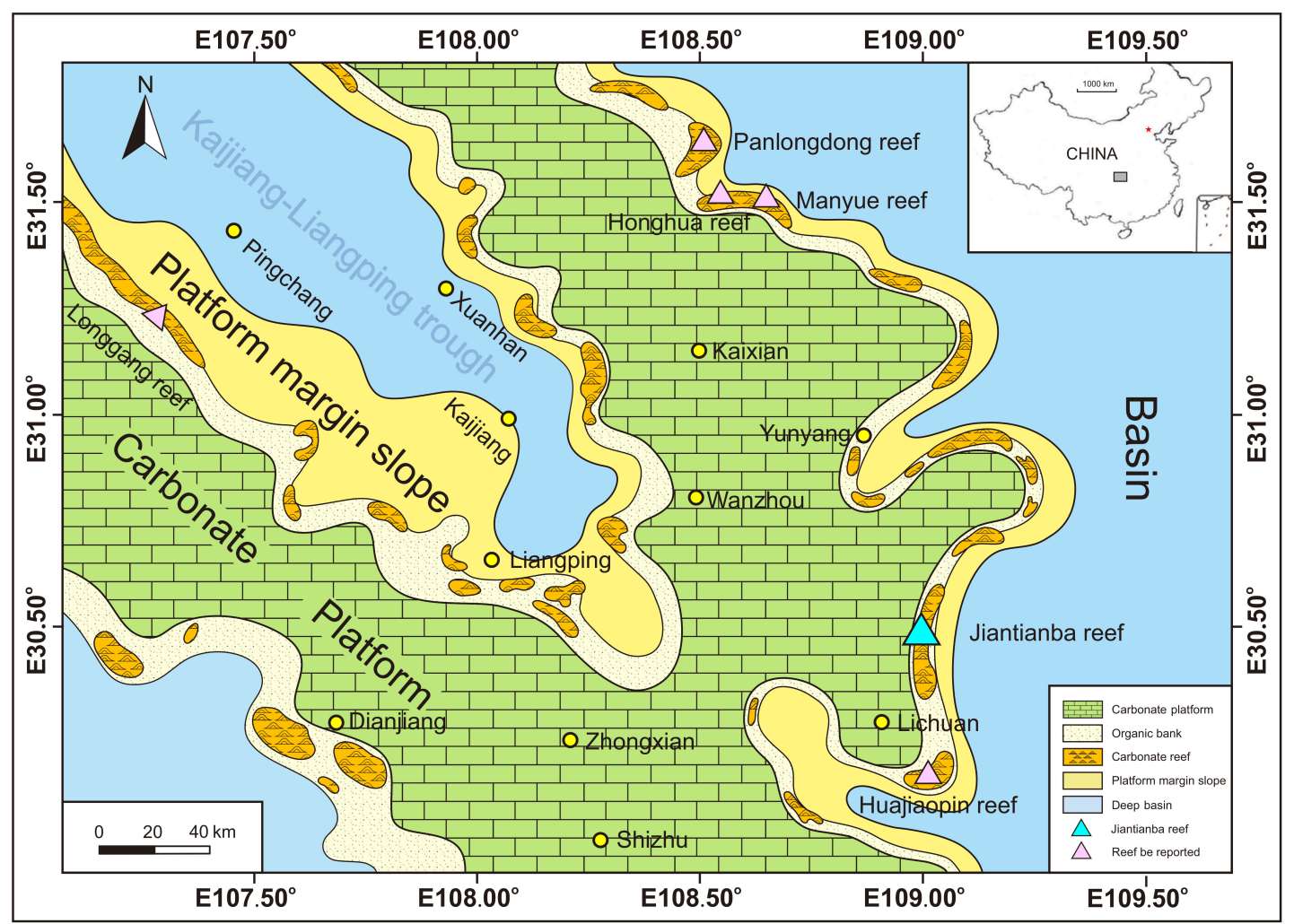

Figure 1. Paleogeography of the Late Permian Changhsingian stage in western Hubei area, south China. The Carbonate platform also belong to the northeastern part of the Sichuan basin. The detailed GPS location of Jiantianba reef is located at $30.4573^{\circ} \mathrm{N} ; 109.0772^{\circ} \mathrm{E}$. The figure is modified from He, Y. B. [11].

Field geology, sedimentary analysis combined both the macroscopic and microscopic observations used to define the lithofacies and to define their sedimentological and environmental setting. The macroscopic lithofacies analysis derived from the reef profile are based on observation from an excellent-exposing quarry with $120 \mathrm{~m}$ long and $50 \mathrm{~m}$ high. The microscopic analysis helps to observe the microstructure of the lithofacies. Evaluating biological components, limestone content, cementation forms, and the role that reefal organisms play in the deposition process, different sedimentary environments have distinguished. The characteristics of the lithofacies associations and successive sedimentary sequences help to reconstruct the paleoenvironment and restore the paleoceanographic information. Based on the above analyses the dynamic growth model of the Jiantianba reef complex is established.

\section{Results}

Eight depositional units were differentiated in field outcrops describing the overall structure of the reef (Figure 3). Furthermore, 12 lithologic facies are distinguished during the identification of the Jiantianba reef lithologies. The filled-skeleton sponge framestone and filled-skeleton sponge bafflestone show the characteristics of constratal growth fabrics, indicating that the constituent organisms grow at a rate similar to that of sediment accumulation, and covered by lime mud sediments. The open-skeleton sponge framestone and binding-skeleton sponge framestone feature superstratal growth fabrics, indicating that the constituent organisms grow higher than sedimentary substratum, creating positive topographic relief. The benthic organism bindstone deposited above the reef framework through adhesion and accumulation. Bioclastic rudstone and microfauna packstone appear only during the last developmental stage of the reef, and they play a significant role in the construction of reef-front filling deposits. 


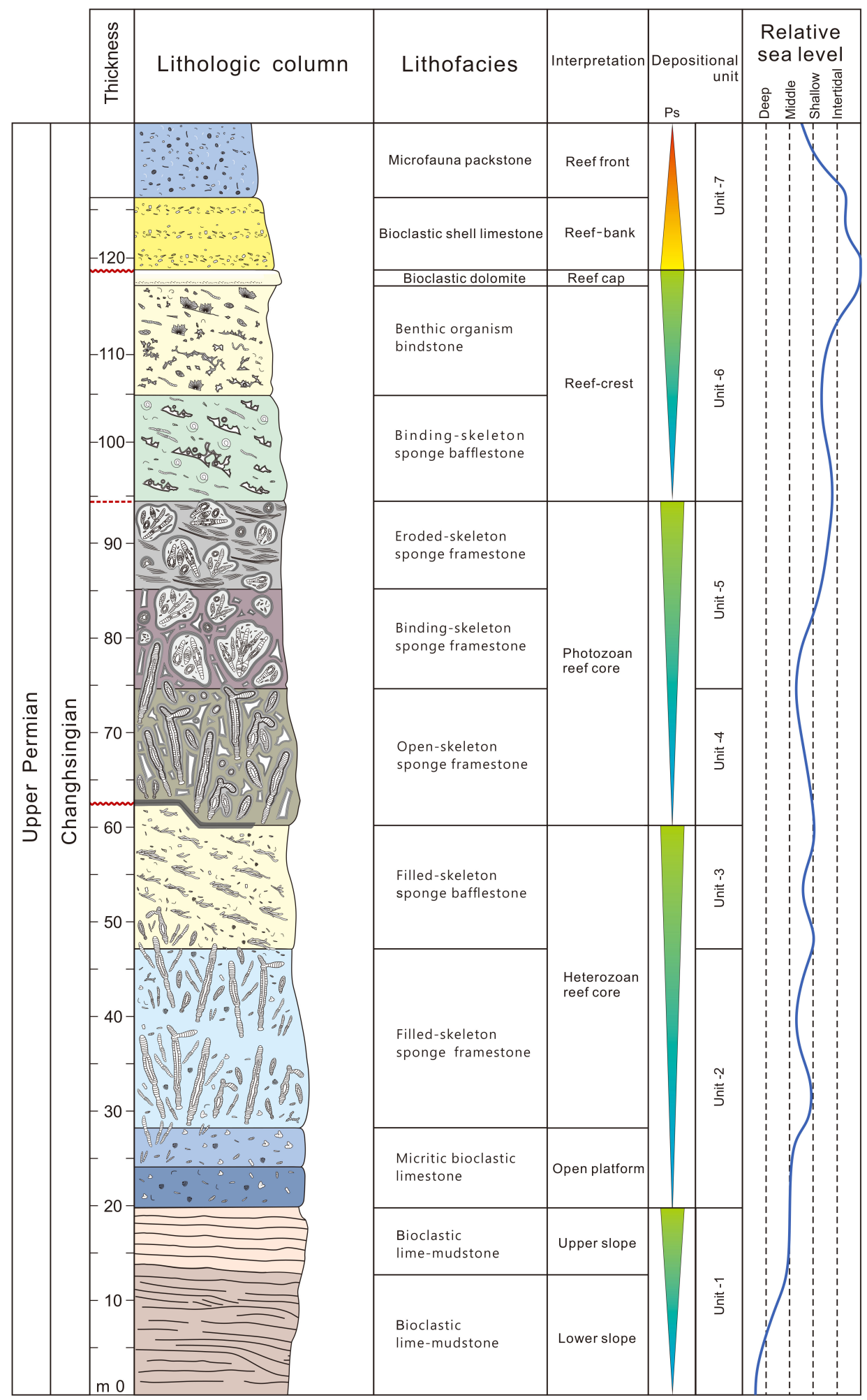

Figure 2. Vertical distribution of lithofacies in the measured stratigraphic and sedimentological columnar sections of the Jiantianba reef. The sedimentary log is from the central part of the outcrop, and the detailed location has marked at Figure 3A. Five parasequences have been identified; the lower four parasequences show the features as upward shallowing cycles. The relative sea level change curve represents the different tendency of the water-depth change in each lithologic section, and the precise explanation has placed in the Section 4.2. 

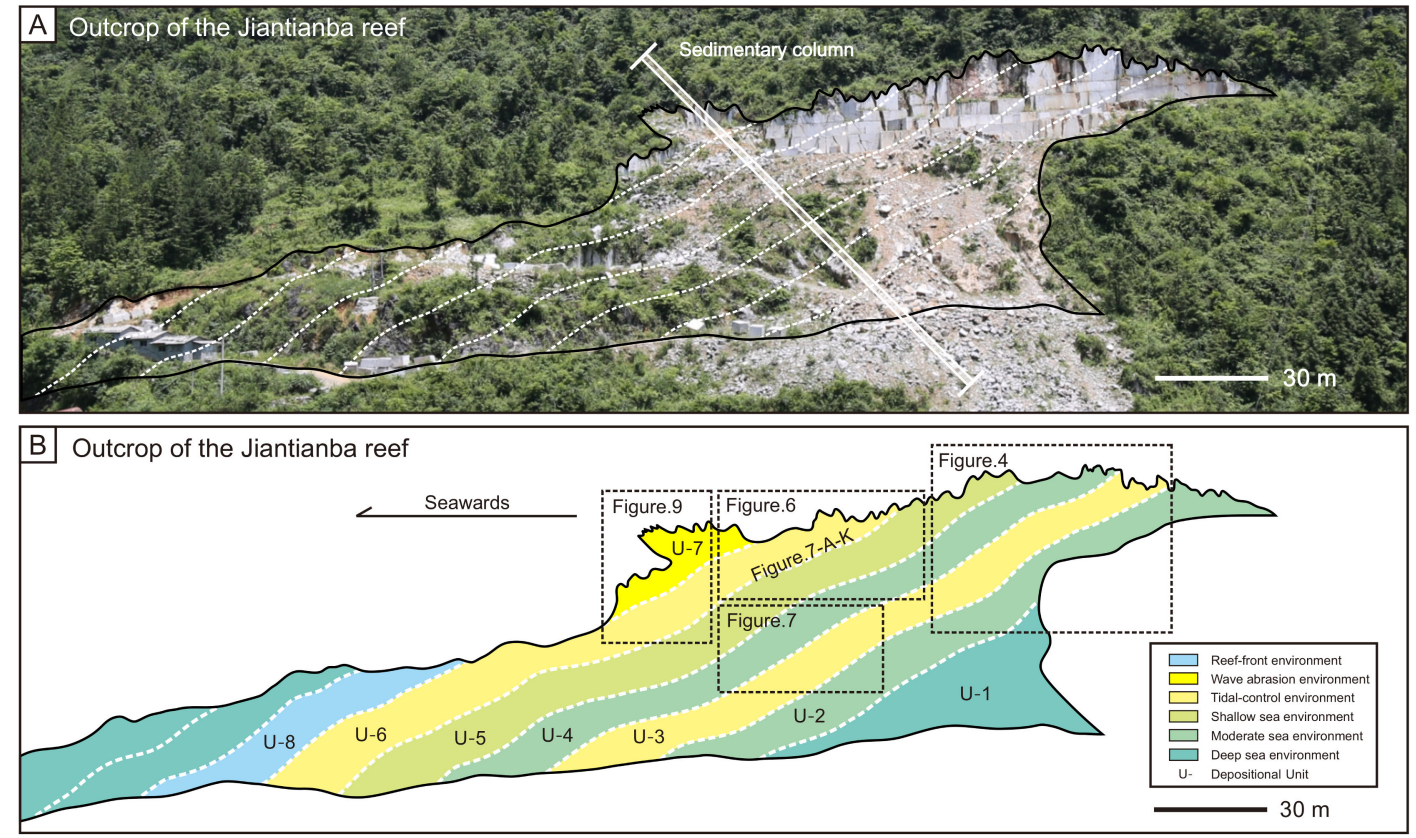

Figure 3. Outcrop profile of the Jiantianba reef: (A) The top is a natural weathered surface of the reef. The interior reef buildup is the smooth plane profile, revealing a complete cycle of a reef formation.

(B) Each depositional unit represents a relatively uniform isochronous stratigraphic unit.

\subsection{Lithofacies Analysis}

\subsubsection{Bioclastic Limestone}

Bioclastic limestone is mainly distributed in the upper part of depositional unit 1 and the bottom of depositional unit 2. Two secondary microfacies are identified: (1) Bioclastic lime-mudstone: moderately to thickly layered bioclastic limestone with muddy strips which are related to the original deposition (Figure 4I). Small irregular pores filled by calcite cement are common. Crinoid stems with lengths of $5-10 \mathrm{~cm}$ are obvious but sparsely distributed in this microfacies. Bivalve, brachiopod and bioclastic components are common; (2) Micritic bioclastic limestone: mainly distributed in depositional unit 2. It is composed of dark gray, massively bedded bioclastic limestone (Figure 4J). Small calcite cement-filled pores are scattered, and escape structures can also be observed. From bottom to top, the biological content is significantly increasing, and the individual bodies of organisms are well preserved. Echinoderms, sponges, foraminifera, brachiopods and bivalves are common. Under the microscope the matrix is mainly composed of dark black bioclastic limestone with calcite strips cement. Small-sized organisms, including foraminifera and crinoids, are abundant (Figure 5E).

\subsubsection{Filled-Skeleton Sponge Framestone}

Filled-skeleton sponge framestone is mainly distributed in the depositional unit 2 . Sphinctozoan sponges constitute the dominant contributor to the framework with an average length ranging from 20 to $40 \mathrm{~cm}$ and a diameter ranging from 1 to $3 \mathrm{~cm}$. They are preserved in situ with erect, leaning or toppled positions (Figure 4D-H). Between the colonies, sponge individuals do not touch each other, leaving interspaces filled with bioclastic limestone. Under the microscope (Figure 5D), the matrix is deemed to be composed mainly of limestone, which shows components similar to those of open platform limestone deposits. Likewise, the content of the sparry calcite cement is limited. Sponges are barely buried by bioclastic limestone. Small-sized organisms, including echinoderms, crinoids, foraminifera, brachiopods and undifferentiated bioclasts are especially abundant. The filled-skeleton sponge framestone features a constratal growth fabric. The sponges as the main reef-builders show that vertical growth occurred at a rate similar to the rate of sediment accumulation. Because the 
sponges do not have a specialized fixation organ and it is therefore difficult to withstand the slow but continuous erosion of seawater [12], upright or leaning growth states represent evidence that the sponges were buried by high-velocity lime mud sediments during growth, resulting in well-preserved sponges. Without large amounts of calcite cavities, the algae encrust are almost absent.
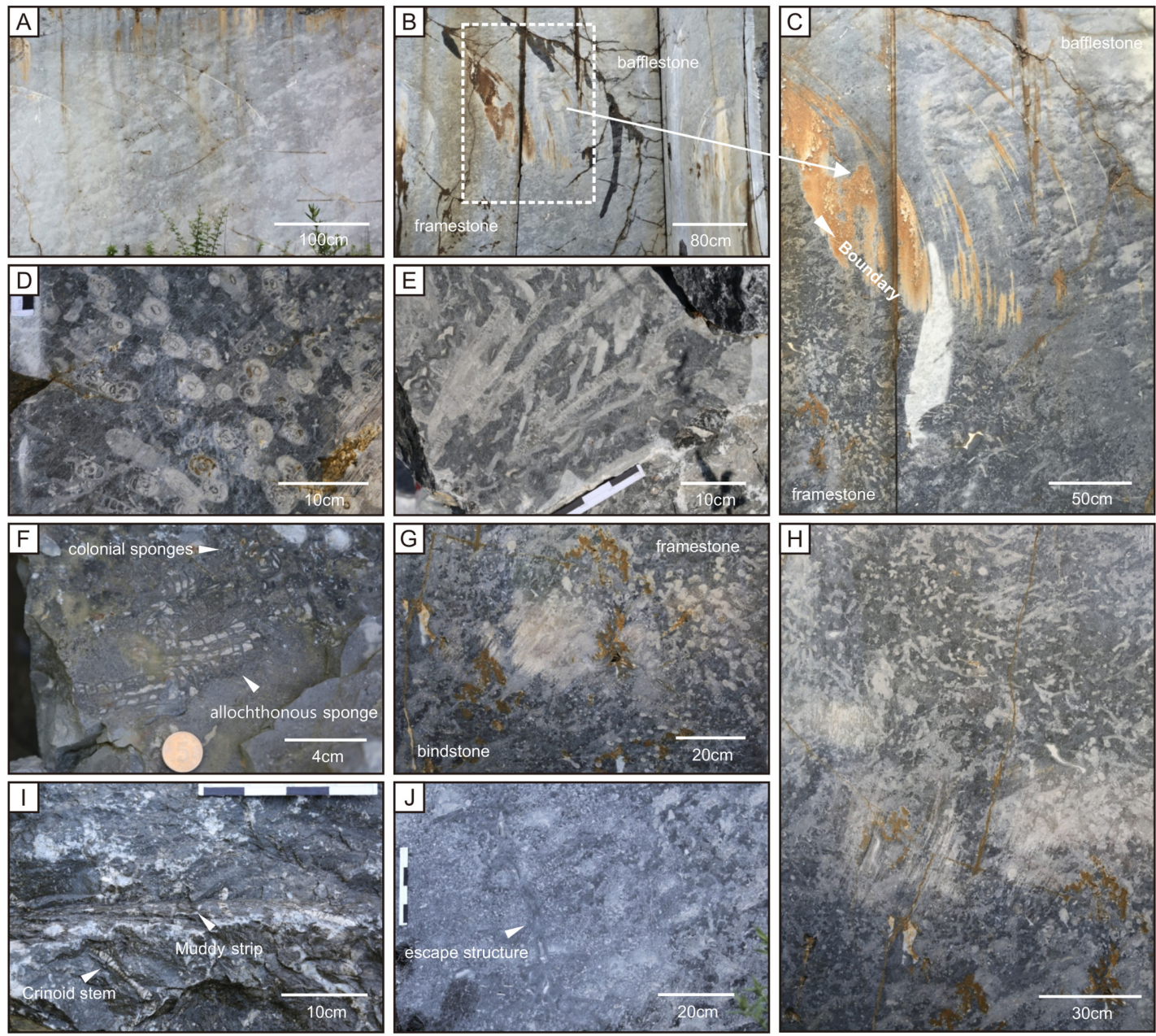

Figure 4. Images of the outcropping lithofacies: (A) filled-skeleton sponge bafflestone composed of dark-gray sponges limestone and light-gray bioclastic limestone; $(\mathbf{B}, \mathbf{C})$ the lateral boundary between the filled-skeleton sponge bafflestone and filled-skeleton sponge framestone; (D) cross-section of the filled-skeleton sponge framestone; Sphinctozoan sponge; (E) longitudinal section of filled-skeleton sponge framestone; (F) allochthonous sponge and in situ sponge colonies; $(\mathbf{G}, \mathbf{H})$ natural transition between dark gray massive bioclastic limestone and filled-skeleton sponge framestone; (I) bioclastic limestone with muddy strips; crinoid stem with lengths of 5-10 cm; (J) massive bioclastic limestone. 

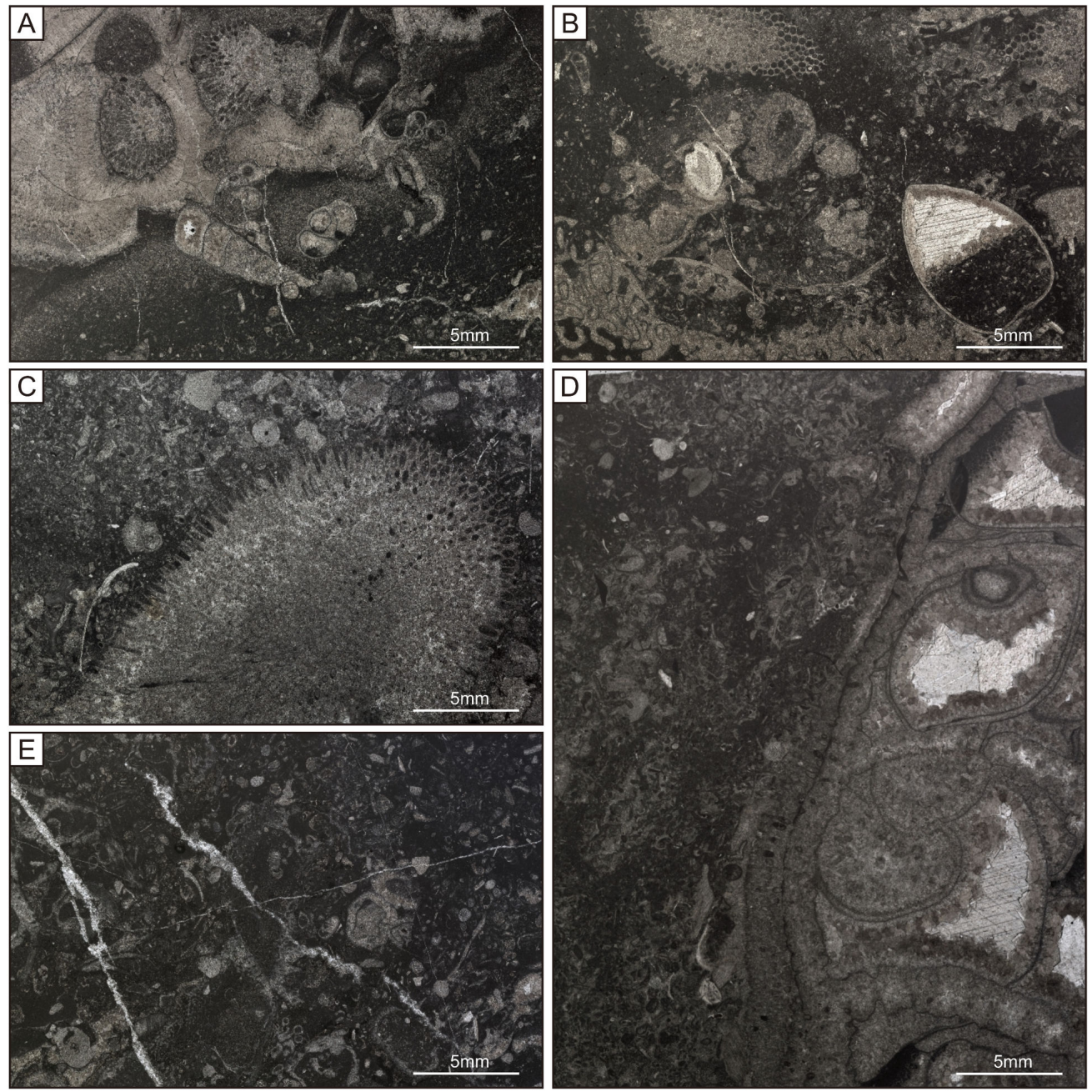

Figure 5. Photomicrographs of microfacies belong to the heterozoan reef core stage: $(\mathbf{A}, \mathbf{B})$ benthic organisms bindstone; pore spaces filled by equant spar calcite cement; (C) Filled-skeleton sponge framestone; (D) filled-skeleton sponge framestone; the chamber of Sphinctozoan sponge;

(E) organisms-bioclastic limestone with calcite veins.

\subsubsection{Filled-Skeleton Sponge Bafflestone}

Filled-skeleton sponge bafflestone is mainly distributed in the middle and upper parts of depositional unit 3. Inozoan and sphinctozoan sponges are the major organisms. Having grown as bunches or clusters, all of the colonial sponges here are leaning, toppled or cling to the sedimentary surface. Compared with the sponges in the framestone, the sponge colonies in the bafflestone consist of 10-30 centimeter-scale layers and bedding with bioclastic limestone layers (Figure 4A-C). In the outcrop profile, filled-skeleton sponge bafflestone show as the dark gray strips and bioclastic limestone layer feature as the light gray strips; hydrozoans and benthic reef-dwellers are common. Under the microscope (Figure 5C), the majority of sponges is barely buried by bioclastic limestone. Algae scarcely encrust the surfaces of the sponges. Toppled sponge clusters degrade the velocity of the bottom currents. They baffle and settle bioclastic sediments and small size reef-dweller on the bottom.

\subsubsection{Open-Skeleton Sponge Framestone}

Opened-skeleton sponge framestone is mainly distributed in depositional unit 4 and the lower part of depositional unit 5. Sphinctozoan sponge is the main organism contributing to the framework. Being well preserved, the sponges have lengths ranging from $15 \mathrm{~cm}$ to $40 \mathrm{~cm}$ and diameters ranging from $1 \mathrm{~cm}$ to $2 \mathrm{~cm}$ (Figure 6I; Figure 7A,B). Laminar algae widely encrust the surfaces of the sponges, 
and black, concentric marine cements wrap around the sponges, hardening the skeleton so that they can support an erect growth position. The open-skeleton sponge framestone features a superstatal growth fabric, suggesting the algae encrusting the sponges and laminated early marine cements consolidate the bodies of the sponges, making them sufficiently rigid to support the upstanding framework. Under the microscope, open-skeleton framestone shows higher contents of algae and cement fabrics with centimeter-scale interspaces between the sponge skeletons is filled with blocky calcite. The limestone content is very low. The fibrous cements usually have broom-like or brush-like shapes (Figure 8G,H). Open-skeleton sponge framestone is the main component constituting the upper part of the reef core, organisms formed a rigid framework during deposition. The model of the reefal lithofacies pattern is shown in Figure 11D.
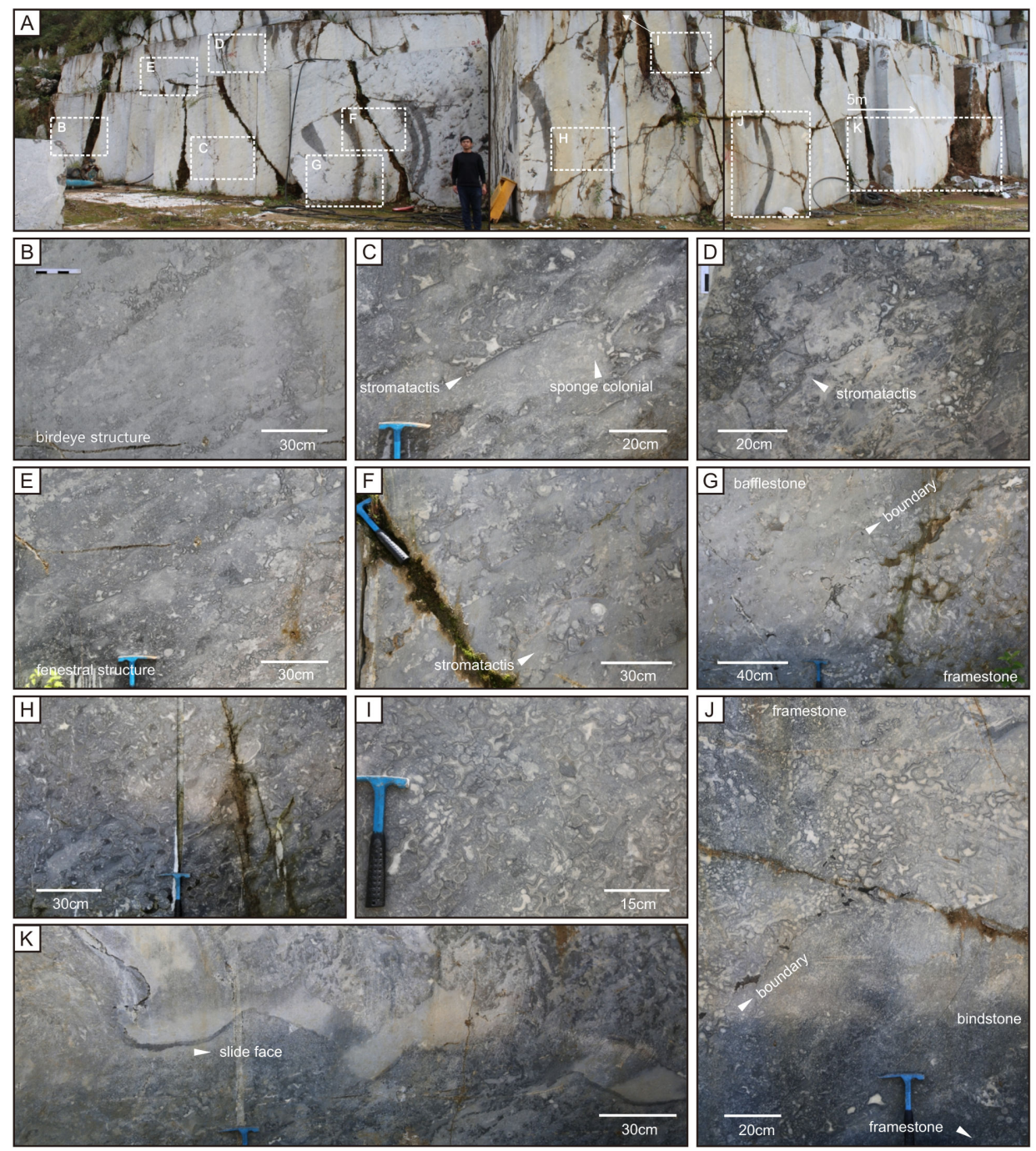

Figure 6. Images of the outcropping lithofacies: (A) profile includes photozoan reef core association and tide-controlled reef crest association of the reef; (B,E) benthic organisms bindstone with fenestral structure; $(\mathbf{C}, \mathbf{D}, \mathbf{F})$ binding-skeleton sponge bafflestone with stromatactis. (G) sedimentary discontinuity face; the boundary between open-skeleton sponge framestone and open skeleton bafflestone. (H) binding-skeleton sponge framestone; (I) open-skeleton sponge framestone. (J) boundary (distal slide) of the framestone and bindstone. (K) slide structure inside the reef core; the boundary between the phase 2 and phase 3 of the reef. 

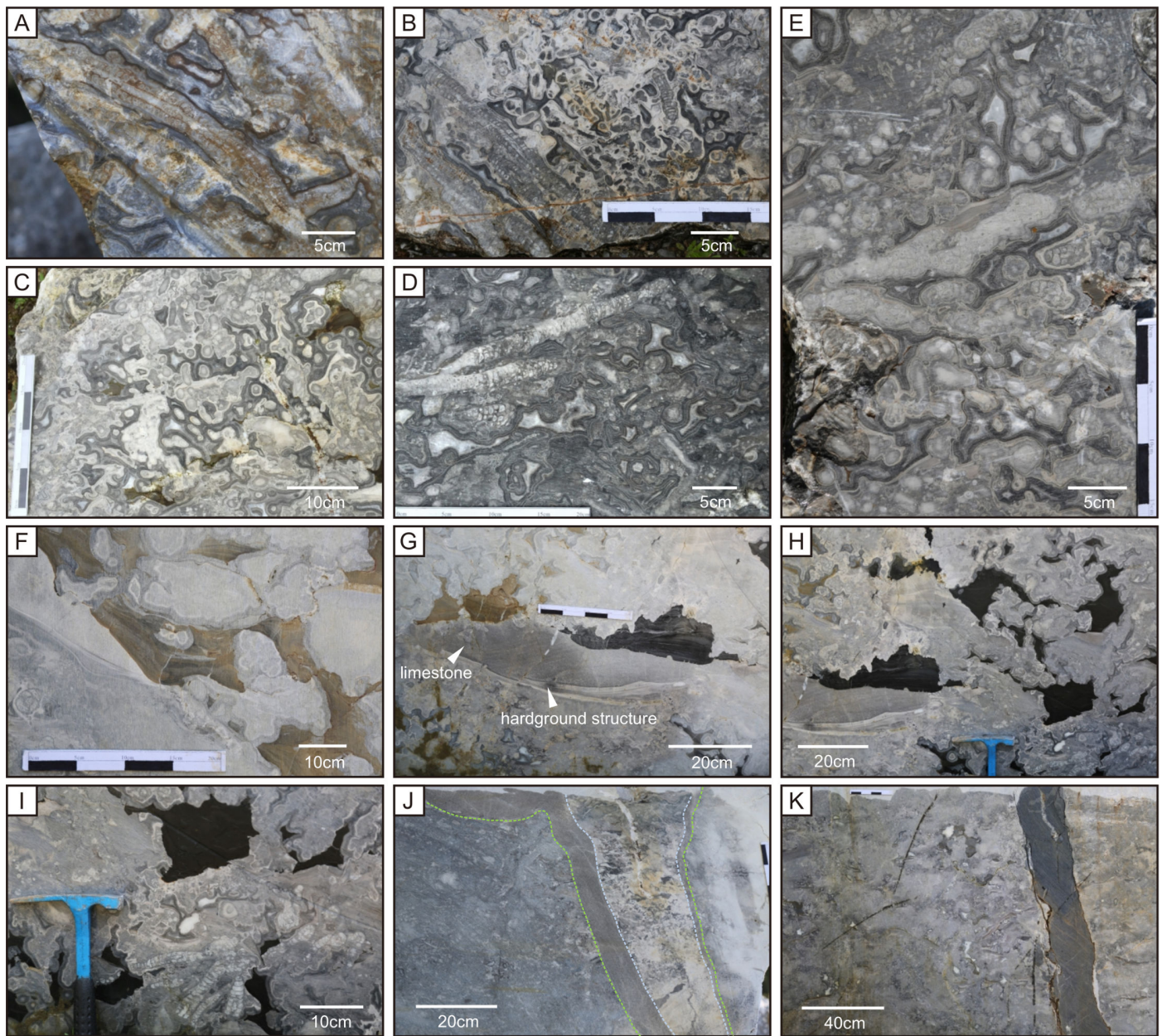

Figure 7. Images of the outcropping lithofacies: (A) open-skeleton sponge framestone; (B) open-skeleton sponge framestone showing upright and toppled position of sphinctozoan sponge colonies. (C) binding-skeleton sponge framestone; cementation binds the densely sponge colonies; $(\mathrm{D}, \mathrm{E})$ binding-skeleton sponge framestone; sponges are in the toppled position; much reef-dwellers are wrapped in the agglomerated blocky mass. (F-I) eroded-skeleton sponge framestone; pore spaces of skeleton filled by allochthonous deposits. (J,K) unique carbonate "discordant dyke-like feature" developed on the reef crest due to cracks on the top of the reef strata filled by unsolidified sediments directly.

\subsubsection{Binding-Skeleton Sponge Framestone}

Binding sponge framestone is mainly distributed in the middle of depositional unit 5 . The skeleton is mainly composed of agglomerated blocky sponges (Figure 6H; Figure 7C-E)). Sphinctozoan, inozoan and hydrozoan are the main reef frame builders. Secondary reef builders bind the sponge skeletons together as a blocSky mass. Additionally, much secondary dwellers are wrapped up within the agglomerated block. Laminated, isopachous cements coat the outside of the agglomerated sponge blocks (Figure 8E,F). The agglomerated block takes up the majority of the space, and the interspatial volume is limited. The walls of the cavities are formed by a black laminar calcite cement, and the interspaces are filled with sparry blocky calcite. They are plenty of secondary reef builders live in the reef skeleton and participate in the construction of the reef, and the organisms form a rigid framework during deposition. The model of the reefal lithofacies pattern is shown in Figure 11C. 

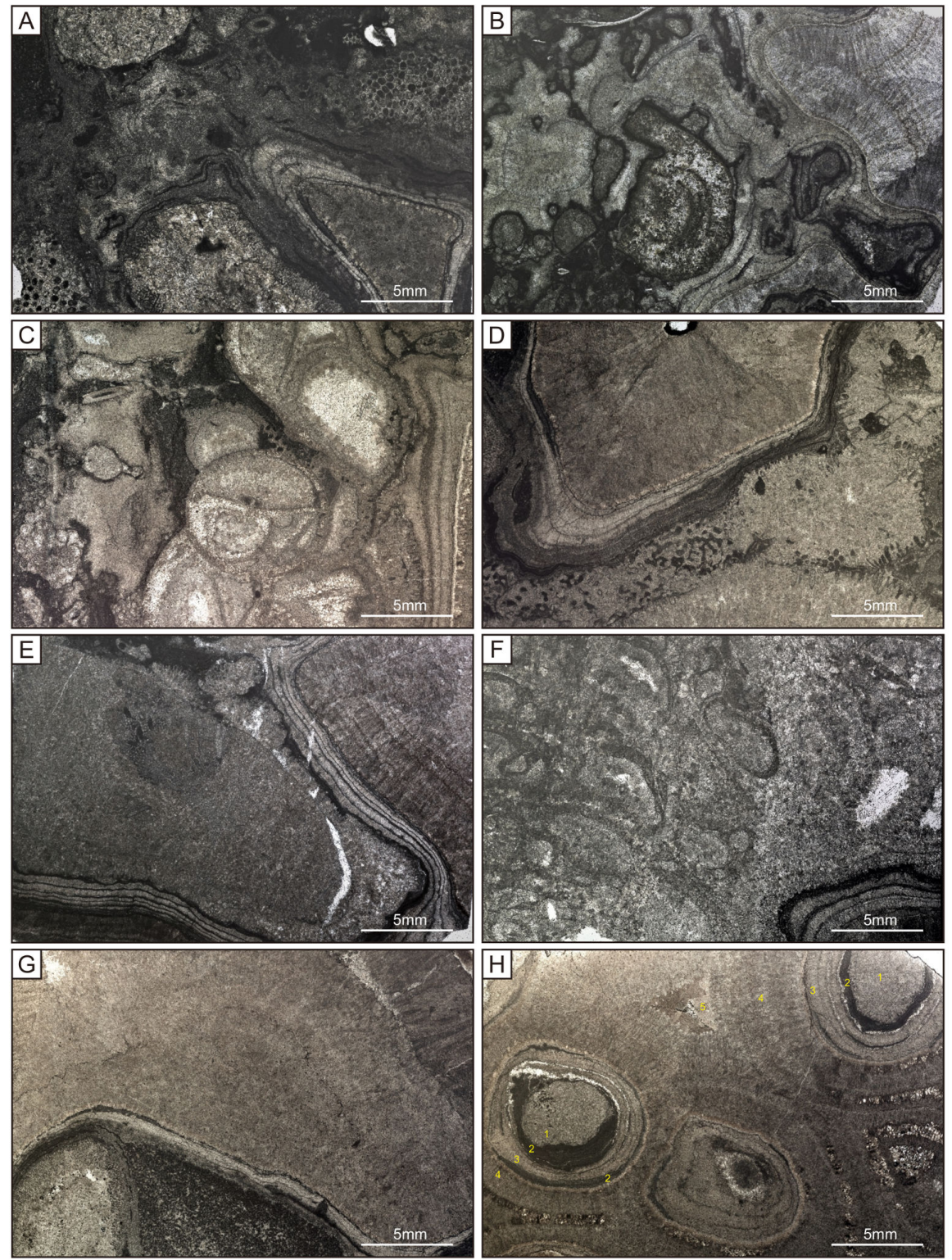

Figure 8. Photomicrographs of microfacies belong to photozoan reef stage: $(\mathbf{A}, \mathbf{B})$ the bioclastic limestone part of the binding-skeleton sponge bafflestone; algae encrusted the sponge; interspace is filled by multiple calcite cement. (C,D) the binding-skeleton sponge part of the bafflestone; fibrous calcite cement wrapped sponge skeleton. (E,F) binding-skeleton sponge framestone; algae and calcite wrapped the out-side of the agglomerated sponge block; $(\mathbf{G}, \mathbf{H})$ open-skeleton sponge framestone showing the filling order between the sponge skeleton: (1) sponge; (2) Archaeolithoporella; (3) fibrous calcite; (4) radiaxial fibrous calcite; (5) blocky calcite.

\subsubsection{Eroded-Skeleton Sponge Framestone}

Eroded sponge framestone is distributed in the upper part of depositional unit 5 . The original skeleton is composed of binding-skeleton sponge framestone. Due to erosion, there are centimeterto decimeter-scale pore spaces between the blocky masses of agglomerated sponges (Figure 7F-I). Two processes of construction and destruction can be clearly observed in the outcrop profile: (1) constructional processes: agglomerated blocks of sponges constitute the original skeleton, and they are coated by a dark gray early marine cement calcite cement. On the bottoms of the cavities, the 1-3-cm scale hardground structure can be observed. Subsequently, limestones with a laminated sedimentary texture are deposited onto the hardground structure as sediment filling; and (2) destructional processes: 
lime-mudstone that carried by bottom current eroded and incised the semi-solid reef framework. In the outcrop, black mudstone with an abundant organic matter content and yellow-brown muddy siltstone sediments filled the pore spaces of the reef skeleton. It indicates that the event deposit of strong current and also demonstrates that contemporaneous semi-solid reef frameworks are sufficiently rigid to resist such a strong hydrodynamic condition.

\subsubsection{Binding-Skeleton Sponge Bafflestone}

Agglutinated sponge bafflestone is distributed mainly in the upper part of depositional unit 5 and the lower part of depositional unit 6 . Figure $4 \mathrm{G}$ shows the boundary between the binding-skeleton sponge bafflestone and the binding-skeleton sponge framestone. Direct observations of the outcrop profile (Figure 6C,D,F) reveal that the lithological characteristics of dense, layered, non-debris features. Sponges with encrusted algae are leaning or toppled, binding together and clinging to the sedimentary surface. The pore spaces of the sponge skeleton are subsequently filled by fibrous calcite. Then the blocky cement formed later. The most significant structural feature in the agglutinated sponge bafflestone is the presence of stromatactis cavities [22-24], which can be clearly observed in Figure 6C. The bottoms of the cavities are extremely flat, and the tops are finger-like or branch-like. The inside walls of the pore spaces are laminated with 1-2 cm thick early marine cements. The remaining spaces of the cavities are filled with sparry calcite. Above the stromatactis, there are gray, bioclastic limestone layers. Plenty of ammonites 5 to $10 \mathrm{~cm}$ in diameter are distributed in the limestone at the lower part of the bafflestone. Under the microscope, the surfaces of organisms are commonly encrusted by multiple dark black layers of algae (Figure 8A,B), and early marine cement fills the remaining interspaces of the lithological framework (Figure 8C,D). Binding-skeleton sponge bafflestone is the main component constituting the lower part of reef cap. The model of the reefal lithofacies pattern is shown in Figure 11B.

\subsubsection{Benthic Organism Bindstone}

Benthic organism bindstone is mainly distributed in the upper part of depositional unit 6 and partly in the upper part of depositional unit 3 (Figure 6B,E; Figure 9K-O). The most significant structural features of the bindstone are fenestral structures, characterized as densely millimeter-scale pores which are filled by sparry calcite cement. In the upper part of the benthic organism bindstone, fan-shaped radially fibrous original aragonite, now calcite, cements are widely developed and filled the pore spaces (Figure 9L), and they are considered to be primordial fiber pseudomorphs. Benthic organisms are extremely abundant, including gastropods, foraminifera, bivalves, and sponges, are abundant, and different types of benthic fauna communities are locally abundant (Figure 5A,B; Figure 10I,J). They are highly enriched at different locations and bound by algae and calcite cement, constituting the upper part of the reef crest. 

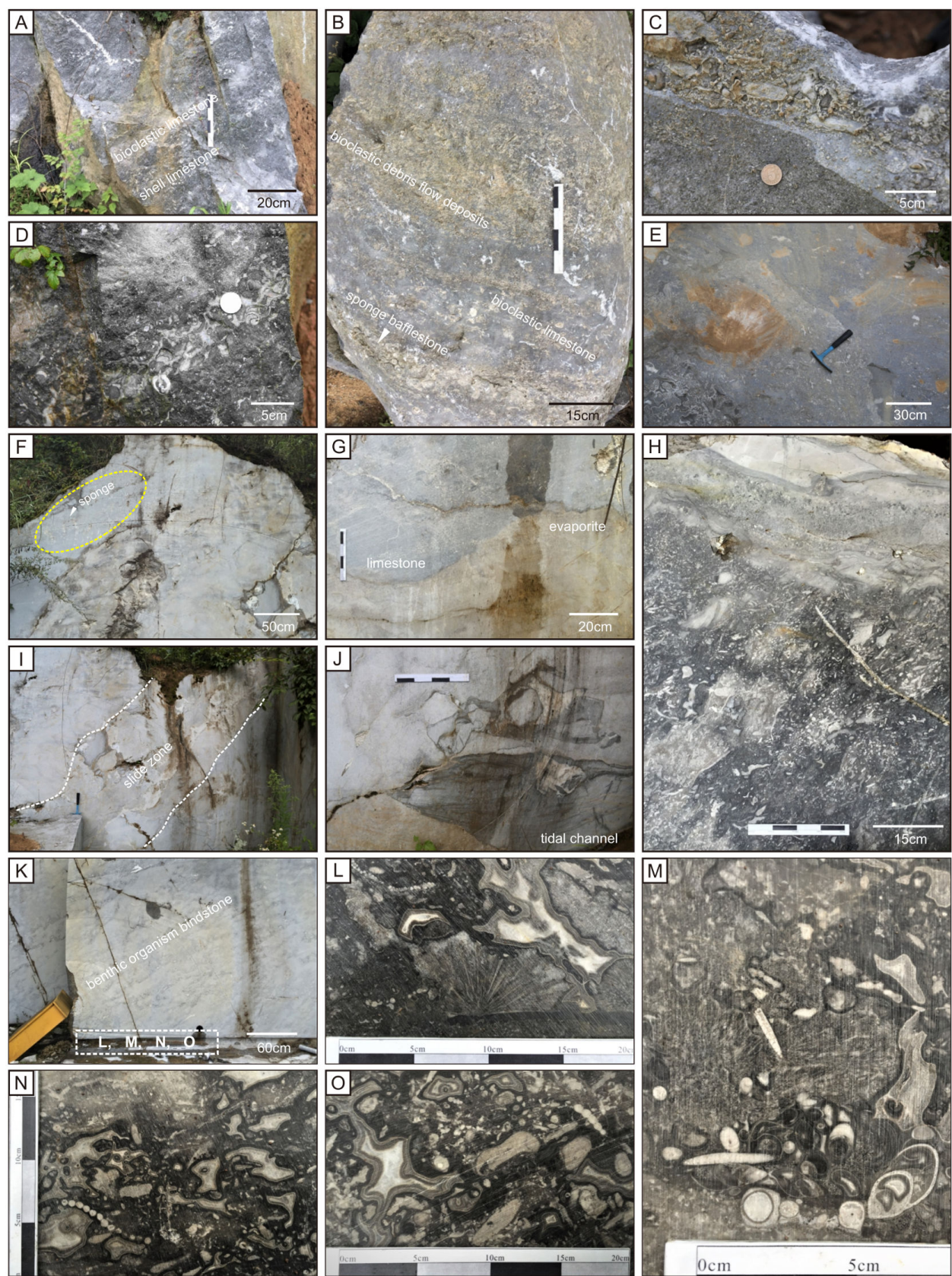

Figure 9. Images of the outcropping lithofacies: (A) benthic-organism bindstone; interbedded dark gray bioclastic limestone and light gray bioclastic limestone; (B) small bioclastic debris flow deposits at the upper part and a 10-20 cm thick sponge bafflestone at lower part; (C) bioclastic debris; (D) benthic-organism bindstone; dense shell layer with shells occluded by sparry calcite; (E) reef front deposits; (F) reef flank slide structure; (G) limestone covers the evaporite rock (the part of reef cap); (J) tidal channel incise the reef cap sediments at the flank of the reef; $(\mathbf{H})$ restricted lagoon; located at the back reef area; $(\mathbf{K}-\mathbf{O})$ benthic-organism bindstone; (L) Fan-shaped aragonite cement.

\subsubsection{Bioclastic Dolomite}

Bioclastic dolomite, representing the reef caps and restricted lagoons, are distributed on top of depositional unit 6 (Figure 9F-J). The bioclastic dolomite reef caps are 1 to $3 \mathrm{~m}$ thick and cover the highest position of the reef. On the backside of the highest position of the reef, the shoal of lagoon is inhabited by a unitary organisms composed of black shells on the order of $1-2 \mathrm{~cm}$ large, densely distributed on the upper part of depositional unit 6 (Figure 9H). On the flank of the reef (i.e., the lower 
part of depositional unit 7), small size faults are developed along the reef-front cliff down to the deeper areas. Above that, the sponge colonies developing in limestone are characterized by small filled-skeleton sponge limestone deposits (upper-right part of Figure 9F). In addition, burrowing structures are visible under the microscope (Figure 10E). The lower part of the burrow hole is filled with bioclastic limestone sediments, and the upper part is filled with calcite cement. Figure 10F-H shows the dolomitized limestone in different parts of the reef. The degree of dolomitization increases from the bottom up. The original composition of the reef cap mainly consists of bindstone and bafflestone in the highest position of the reef.
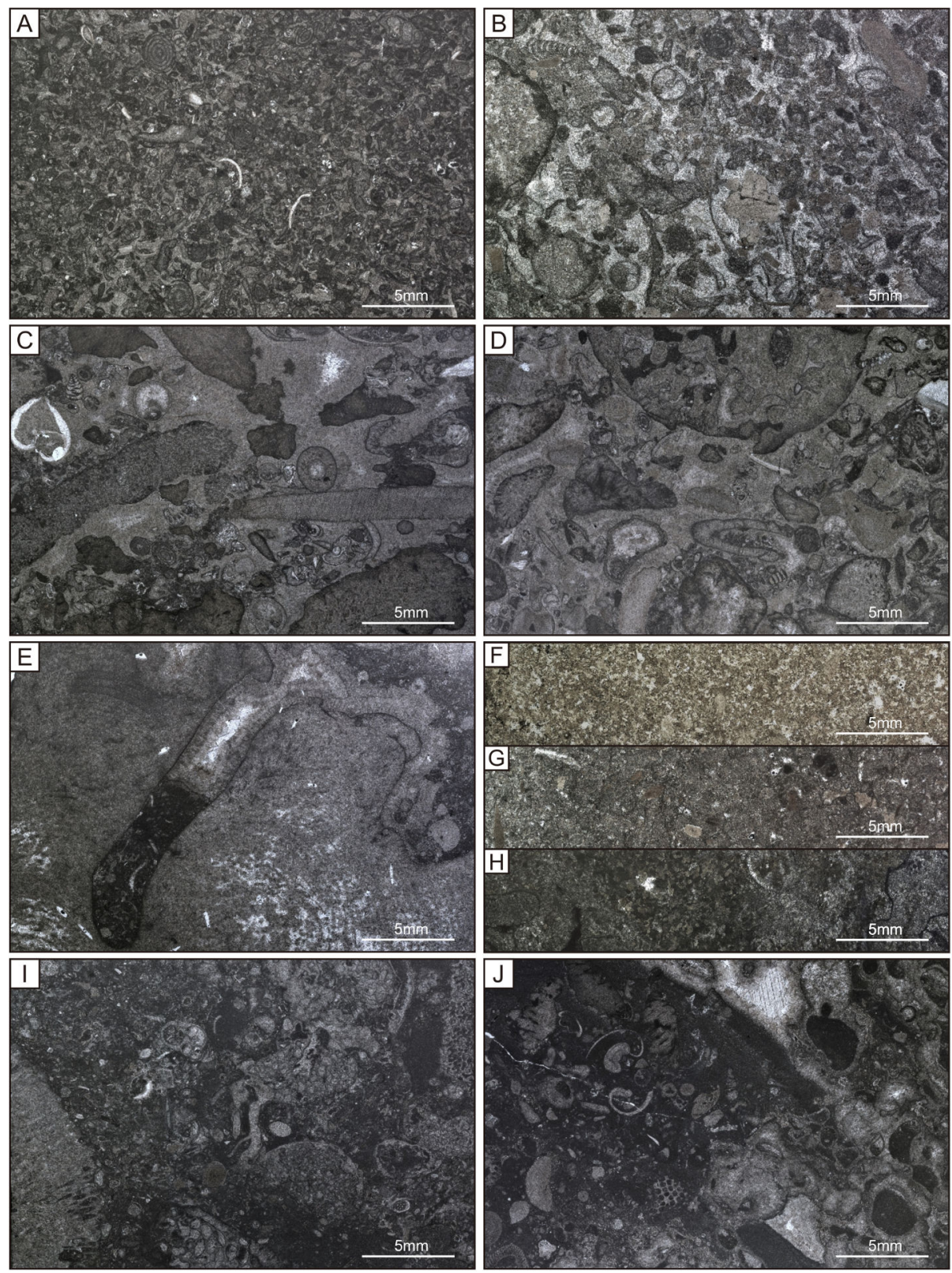

Figure 10. Photomicrographs of microfacies: (A) microfauna packstone; (B) bioclastic rudstone; (C,D) matrix of reef-bank shell limestone with abundant benthic fauna; (F) surface of reef cap; lower part of the burrowing hole filled by limestone and the upper part filled by calcite cement; $(\mathbf{F}-\mathbf{H})$ reef cap under different degree of dolomitization; $(\mathbf{I}, \mathbf{J})$ benthic organisms bindstone. 


\subsubsection{Reef-Bank Shell Limestone}

Reef-bank shell limestone is mainly distributed in the higher part of depositional unit 7 above the higher position of the reef. In the outcrop profile (Figure 9A,D), the reef-bank shell limestone features dark gray shell limestone beds with light gray bioclastic limestone. With an average thickness ranging from 20 to $30 \mathrm{~cm}$, the dark gray shell limestone contains extremely abundant bivalve and brachiopod organisms. The sizes of those organisms are commonly between 1 and $5 \mathrm{~cm}$, and their contents can reach more than $80 \%$ in the limestone. With an average thickness ranging from 10 to $20 \mathrm{~cm}$, the light gray limestone contains abundant bioclastic debris, including sponges and echinoderms. The small size pores between the benthic organisms and bioclast are cemented by calcite (Figure 10C,D). The biological shell limestone mainly located at the higher part of reef back. It is the essential component contributing to the reef bank deposits.

\subsubsection{Bioclastic Rudstone}

Bioclastic rudstone, representing debris flow deposits, are mainly located in the middle part of depositional unit 7, at the flanks of the reef (Figure 9B,C,E). The initial stage of bioclastic debris flow deposits is observed above the high part of the reef buildup (Figure 9B). Several sets of bioclastic rudstone, incising the previous limestone, are developed at the upper part. The sorting and roundness degree of the gravel debris are relatively poor (Figure 9C). Bioclastic debris, including sponges, echinoderms, bivalves and brachiopods, are common. Figure $9 \mathrm{E}$ shows the bioclastic rudstone deposition in the reef-front slope areas. Three prominent phases are recognized: (1) coarse-grained bioclastic rudstone: the half-diagenesis state reef debris are from the reef collapse and has been carried by debris flow to here; (2) In the middle section is a set of coarse-grained bioclastic rudstone; bioclastic fragments from the reef structure are abundant, and allochthonous sponge skeletons are common; and (3) At the top is a set of small-grained bioclastic limestone, in which the sedimentary particles are relatively fine, and there are relatively few coarse fragments. Bioclastic rudstone represents the environment in front of the reef.

\subsubsection{Microfauna Packstone}

Microfauna packstone is mainly distributed in the lower part of depositional unit 8, representing the reef-front filling environment, are mainly located in the distal front of the reef. They are an essential component of reef front filling deposits. In the field, this lithofacies shows as the fine gray limestone with several meters thick. Under the microscope (Figure 10A), the packstone consists of abundant microfauna such as foraminifera, bivalves, and gastropods. The other kind of microfauna packstone which have more debris contents is mainly distributed in the upper part of depositional unit 8. Under the microscope (Figure 10B), it is mainly composed of foraminifera, gastropods and bioclastic debris. These massive supply of the debris deposits and suspended sediment deposits at the distal of the reef-front area.

\subsection{Lithofacies Association}

\subsubsection{Heterozoan Reef Core Association}

The heterozoan reef core association consists of the bioclastic limestone, filled-skeleton sponge framestone and filled-skeleton sponge bafflestone. These lithologic facies feature constratal growth fabrics, that is, the organic accretion occurred at a rate similar to the rate of sediment accumulation. Sponges here are not rigid enough to support the lithologic skeleton but play the role of fixation of the uncompacted sediments. The matrix consists mainly of bioclastic limestonebut the difference is: (1) in the filled-skeleton sponge framestone, the sponges reveal an upright position and they are the main components constituting the lithofacies; (2) filled-skeleton sponge bafflestone is made of autochthonous organisms which baffled the deposits and shows the interbedding structure with bioclastic limestone. On the top of this lithologic section, the discontinuity surface (Figure $6 \mathrm{~K}, \mathrm{~J}$ ), as the small-scale slide 
structure, represents the upper boundary of the heterozoan reef core association. The heterozoan reef core association has the following features: (1) the branches of the sponge skeleton organisms develop in intervals and rarely come into contact with each other; (2) the reef matrix is dominated by mud limestone with relatively little early marine cement and calcite in the cavities; (3) algae are rare and are slightly encrusted few sponge skeletons; (4) the main organisms are heterotrophic and lack a biological binding process within the reef framework, and (5) the outline of the heterozoan reef core association buildup feature as a slightly uplifted geomorphological mound.

\subsubsection{Photozoan Reef Core Association}

The photozoan reef core association consists of the open-skeleton sponge framestone, binding-skeleton sponge framestone and eroded-skeleton sponge framestone (Figure 6A). These lithologic facies feature superstratal growth fabrics, that is, sponge skeletal support enables them to raise themselves above the substrate. Sponge skeleton and other reef-builder organisms contact each other and the space pores between them remain open during the early stages of reef growth. The processes of encrusting algae, early marine cements strengthen the rigidity of sponge skeleton. Bioclastic limestone is commonly rare in the matrix, the difference between those lithofacies is: (1) binding-skeleton sponge bafflestone consists of the toppled sponges bound by algae and filled by calcite cement, and shows the interbedding structure with bioclastic limestone; (2) the binding action of the binding-skeleton sponge framestone takes place on the basis of sponge skeleton and filled with their pore spaces; (3) open-skeleton sponge framestone is the rigid framework encrusted by algae and early marine cements, and the pore spaces filled with late calcite cement. In the upper section, eroded-skeleton sponge framestone represents the erosional processes of the reef. This phenomenon proves that the semi-solid reef core already rigid enough to resist certainly strong currents. The top of the reef core shares a distinct sedimentary boundary with the reef crest (Figure 6G), representing the end of the development of the photozoan reef core association. From the microfacies observation, the typical lithologic combination order consists of: (1) sponge skeleton; (2) algal layer; (3) fibrous calcite cement; (4) radiaxial calcite cement; and (5) blocky calcite. A large number of pores that are filled with calcite cement between the pore spaces of the skeleton. Significant biological binding effect and calcite cement are characteristic of photozoan elements. The outline of the photozoan reef core association buildup feature as a more significant uplift in geomorphic unit.

\subsubsection{Tide-Controlled Reef Crest Association}

The tide-controlled reef crest association consists of the binding-skeleton sponge bafflestone, benthic organism bindstone, thin dolomitized reef cap and small-scale restricted lagoon. Mainly featuring as tabular growth fabric, the reef crest strata cover the outline of the reef core framestone with the form of adhesion and accretion. At the bottom part of the reef crest, binding-skeleton sponge bafflestone is marked by stromatactis cavities, indicating a sub-tidal to intertidal depositional environment. Upward, benthic organism bindstone is developed in the middle section; it mainly consists of benthic organism communities and limestone. Fenestral structure have been formed mainly in the intertidal to supratidal marine environment. In addition, the tidal channel (Figure 9J) can be a good evidence of tidal action. On the top of reef crest, the emergence of the dolomitic reef caps and small-restricted lagoon represents the end of development of reef buildup. The unique carbonate "discordant dyke-like feature" developed on the reef crest due to cracks on the top of the reef strata filled by unsolidified sediments directly (Figure 7J,K). The reef crest association is mainly controlled by the effects of tides; as a result, the outline of the reef crest becomes more contoured and planar. Gravel and debris are absent at this stage.

\subsubsection{Reef-Bank Association}

The reef-bank association of the Jiantianba reef mainly consists of the reef-bank shell limestone, bioclastic debris flow, and reef-front filling deposits. During the short exposure of the Jiantianba reef, 
the reef buildup is dominated by wave activity, and contributing to the reef-bank depositional system. In the reef-back setting, multiple sets of moderately to thickly layered bioclastic limestone embedded with beach shell limestone are developed at the higher parts above the reef crest. Bioclastic debris flow deposits at the initial stage in front of the reef slopes are observed, providing bioclastic debris sediments toward the deeper sea. In the distal reef-front area, reef-front filling deposits layers are inclined to seaward. The lithologic facies consist of bioclastic sponge floatstone, microfauna packstone and bioclastic rudstone. Large amounts of breccia and grains are developed in this depositional association.

\section{Discussion}

\subsection{Sedimentary Interpretation of the Lithofacies}

Twelve lithologic facies are distinguished during the identification of the Jiantianba reef lithologies. Each of the lithofacies corresponds to a different oceanographic environment. From a reefal growth fabrics perspective, the six main lithofacies constituting the reef structure, and their lithologic pattern shown in Figure 11. These lithofacies patterns can widely apply to the identification of reefal lithofacies in the South China area during the Late Permian $[25,26]$.

The various lithofacies associated with the reef complex system constitute the reef buildup. Each of these lithofacies characteristics correspond to a specific sedimentary environment [27,28]. The bioclastic limestone represents the substratum for reef growth and evolution. It developed in the deep-water surrounding with the high sedimentary rate of limestone. The filled-skeleton sponge framestone represents the kind of constratal growth fabric, and the open-skeleton sponge framestone is typical of superstratal growth fabric. In a superstratal growth fabric, the constituent organisms are collectively stacked decimeters to meters above the substratum, creating positive topographic relief. In contrast, constratal growth fabric occurs when vertical organic accretion occurs at a rate similar to that of sediment accumulation [2]. In the filled-skeleton sponge framework, the autochthonous sponges exhibited the upright position. They grew in the environment of the high sedimentary rate so that the limes mud deposits rapidly filled the interval space of the skeleton. The filled-skeleton sponge framestone represents a moderate to depth environment with muddy water. The matrix content is similar to the bioclastic limestone. By contrast, filled skeleton sponge bafflestone control by the action of the current. The sponges here are leaning or toppled, and interbedding with bioclastic limestone. The bioclastic content in the filled-skeleton sponge bafflestone is much higher than the filled skeleton sponge framestone. Open-skeleton sponge framestone is the main component constituting the rigid reef core. The accumulation rate of limestone sediment between the framework is meager, but chemical sedimentation is quite developed. The pore spaces filled with late calcite cement. It represents the sedimentary environment within the photic zone. Binding sponge framestone composed the upper part of the reef core. During the growth phase of the reef, plenty of reef builders inhabited between the sponge framework and secreted a large amount of calcium carbonate to reinforce the reef framework. It develops in a middle-shallow water environment. Binding-skeleton sponge bafflestone developed in a sub-tidal to intertidal environment with relatively strong hydrodynamic condition. In contrast, benthic organism bindstone represents an intertidal to supratidal environment in which the hydrodynamic conditions are relatively weak. Bioclastic dolomite represents a semi-restricted evaporation environment which developed in the reef-back lagoon. Reef-bank shell limestone facies represents an environment characterized by stronger hydrodynamic due to wave action. Bioclastic rudstone represents the debris flow deposits in the front of the reef environment. Microfauna packstone represents the suspended sediment. It constitutes the strata of the reef-front filling deposits where the original sedimentary environment is in the shallow sea. 


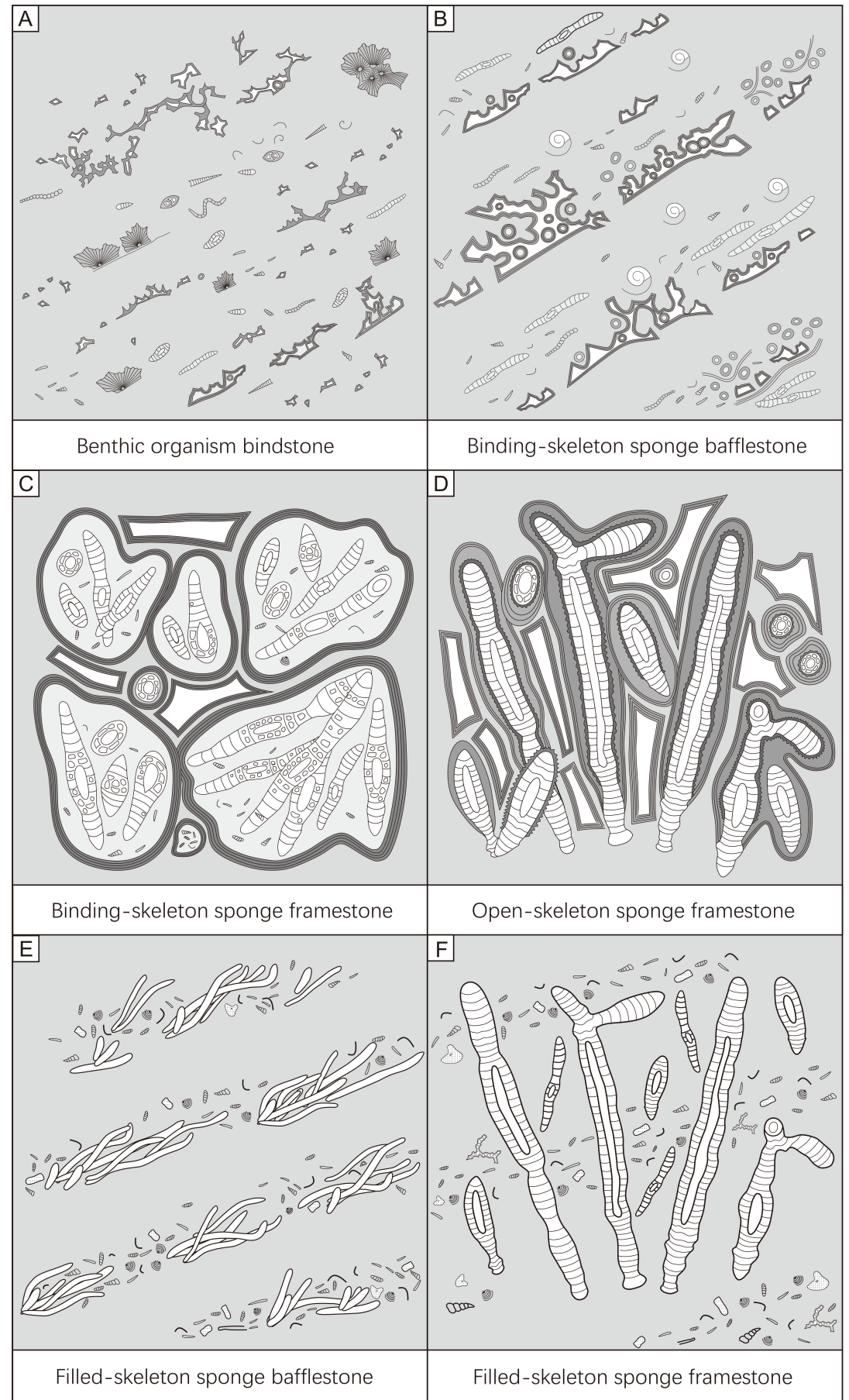

Figure 11. The model of the reefal lithofacies pattern. (A) benthic organisms bindstone: The algae and calcite cement bound and encrusted benthic organism fauna and formed bindstone. (B) binding-skeleton sponge bafflestone consists of algae and calcite cement bound the toppled sponges (C) binding-skeleton sponge framestone: binding action takes place on the basis of skeleton formation, wrapping the skeleton up and strengthening the framework. (D) Open-skeleton sponge framestone is the rigid framework encrusted by algae and early marine cements. The pore spaces filled with late calcite cement. (E) Filled-skeleton sponge bafflestone is made of autochthonous organisms which baffled the deposits and shows the interbedding structure with bioclastic limestone. (F) fill-skeleton sponge framestone: the sponges reveal an upright position and they are the main component constituting the lithofacies. The matrix is bioclastic limestone. 


\subsection{Relative Sea Level Change and Oceanographic Environment}

The characteristics and combination of lithologic phases reveal the relative sea level changes $[29,30]$. Because the outcrop of the reefal profile reveals the complete reefal sequence from the upper slope to the reef cap deposits, successive trends of the relative sea level can be inferred by the characteristics of sedimentologic evidence, especially they only have two small-scale depositional discontinuity surfaces and one erosional surface (reef cap) within the reef profile. From the bottom to the top, each lithofacies association represents a special depositional environment. In the bottom, the lower slope and upper slope deposits represent a relative deep-water setting. Upward, filled-skeleton sponge framestone and filled-skeleton sponge bafflestone reveal the muddy water environment which is below the marine euphotic zone. They are dominated by the suspension deposits and lacked signs of photosynthesis process, and also, the hydrodynamic conditions are very weak. It represents a middle water deep environment. The open-skeleton sponge framestone and binding-skeleton sponge framestone represent the depositional environment within the marine euphotic zone. There are more abundant reefal species, and signs of the photosynthesis process are common. Some small-scale hard ground structures can be observed within those facies which can indicate that they developed during the relatively stable sea level. This lithofacies represents a middle-shallow water deep environment. Fenestral structure and stromatactis within the reef cap have been formed mainly in inter- to supratidal settings, and also, we can observe the tidal channels here. Finally, the bioclastic rudstone and reef-bank shell limestone are related to very shallow sea with wave action. They represent a shallow water environment.

\subsection{Dynamic Development Model of the Jiantianba Reef Complex}

Palaeogeographic conditions, such as tropical and subtropical realm reveal the two distinct carbonate forming environments [31]. The carbonate sedimentation affected by relative sea level change determines the stacked pattern of reef internal structural units [32]. Oceanographic conditions between the different water stratification, including not only the nutrient, salinity, and temperature but also the hydrodynamic condition, determine the different kinds of the lithofacies association $[6,7]$. Taking the above into account, 4 phases of the development of the Jiantianba reef is suggested here (Figure 12): (1) the heterozoan reef core stage; (2) the photozoan reef core stage; (3) the tide-controlled reef crest stage; and (4) the reef-bank stage. The heterozoan reef core stage developed in the marginal platform with cold and muddy water surrounding. At the bottom, a set of dark gray massive bioclastic limestones develop in the open platform environment as the substratum of the reef. Sponge colonies attached to the lime mud sediment grow rapidly and are buried by lime mud sediment at the same time. As the result, the rate of sea level rise is comparable to the rate at which reef strata develops. Since the Jiantianba reef paleotropical region, it suggests heterozoan reef core stage may have been affected by the upwelling flow. In this stage, the relative sea-level is relatively high and the hydrodynamic condition gradually strengthen. The photozoan reef core stage developed within the photic zone. From the bottom to the top, the reef core experienced a process of relative sea level decline. Upwards, it is an increasing number of secondary reef-builders living within the sponge skeleton with calcite cement that agglomerates the sponges into blocks. On the upper section, the eroded-skeleton sponge framestone represents the depositional event of the strong currents. During this phase, the relative sea level continuously declines, and illumination and nutrition of the sea water continue to increase. During the tide-controlled reef crest stage the water depth of this phase is very shallow and tidal action dominated the characteristics of lithofacies. On the bottom part, stromatactic structure indicate a sub-tidal to intertidal depositional environment. Upward, benthic organism bindstone with fan-shaped aragonite cements indicate an intertidal to supratidal marine environment. On the top of reef crest, the emergence of the dolomitic reef caps and small, restricted lagoons represents the final exposure of the reef. The entire sedimentary process of the reef crest traverses from the ocean subtidal zone to the exposed environment. During the reef-bank stage, reef sedimentation process is dominated by wave abrasion 
during the short exposure. Debris contents extremely developed at this stage. The integrated reef buildup functions as an anti-wave morphological unit rather than the encrusting sponge framework.
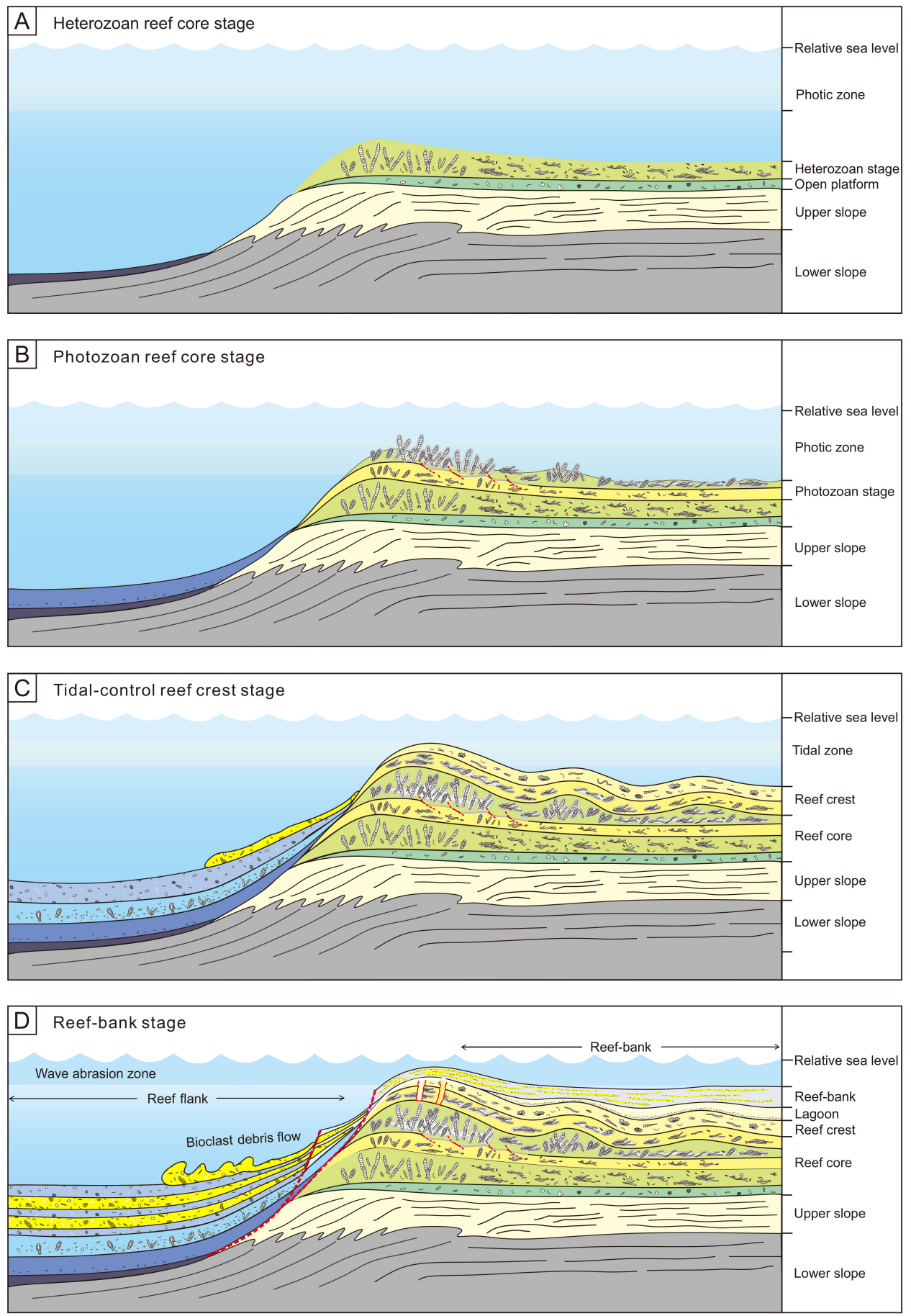

Figure 12. Dynamic development model of the Jiantianba reef complex. The development of Jiantianba reef consists of four phases: (A) the heterozoan reef core stage: reef developed in the marginal platform within muddy surroundings; (B) the photozoan reef core stage: reef developed within the photic zone, and water is warm and the illumination is adequate; (C) the tide-controlled reef crest stage: reef crest developed in the very shallow depth and controlled by the tide action; (D) the reef-bank stage: sedimentation process is dominated by wave abrasion and bioclastics contents extremely developed. 


\subsection{Implications for Comparative Analysis}

The Western Hubei area belongs to the Sichuan Basin which situated in the western part of the Yangtze Craton. The entire platform of the region belongs to the tropics during the Permian period. On the eastern side of the margin of the carbonate platform, Panlongdong, Manyue and Huajiaoping reef and Jiantianba reef exposed on the surface [25,33-35], providing a favorable basis for the horizontal comparison of regional reef developments. Three prominent sedimentary cycle have been distinguished within these reefs, indicating their development are controlled by similar oceanographic condition and the uniform relative sea-level change. In contrast, platform marginal reefs developed at both sides of the Kaijiang Liangping trough, such as Yuanba and Puguang as indicated by seismic data, logging information and well core [36-38]. The giant Puguang gas field discovered in the eastern Sichuan which is located at the eastern side of the Kanjiang Liangping trough. The gas reservoirs consist of the platform-margin reef and shoal facies. Zhao [36] reported that the Longgang and Maoba reef gas.

Reservoir share similar features of the Puguang Changhsingian Formation; the lithofacies including dolomitized biolithites, dolomitized bioclastic limestones, and bioclastic micritic dolomites. Two depositional systems of the reef are recognized in the Yuanba gas reservoirs, including a homoclinal ramp and a rimmed carbonate platform system [37-39]. All the major lithofacies discerned within the Yuanba core sample, including framestone, bafflestone, bindstone, bioclastic packstone/grainstone/wackestone and dolomite, can correspond to the Jiantianba reef study. The reef-bank association, especially in reef front area, can be a contrast to the internal-shoal facies and the inter-shoal/inter-reef sea facies. The reef crest association can be linked with the restricted lagoon facies and marginal-shoal facies. The photozoan reef core association is consistent with marginal-reef facies which describe as the platform-interior patch-reefs. The heterozoan reef core association, especially substratum part of the reef, interpret as the homoclinal ramp.

\section{Conclusions}

Integrated field geology, sedimentary analysis combined both the macroscopic and microscopic observations of the Jiantianba reef complex allow for the following conclusions:

1. Twelve lithofacies have been distinguished according to their sedimentary components and growth fabrics. Each lithofacies indicates a specific depositional environment. From the bottom to the top, three major upward-shallowing cycles are shown, with lithofacies changing from carbonate sedimentary system to clastic rock sedimentary system.

2. The Jiantianba reef is divided into four different but coherent lithologic associations: the heterozoan reef core association, the photozoan reef core association, the tidal-control reef crest association and a reef-bank system association. All these lithological association can be correlated to different stage of the reef development.

3. Dynamic development model of the Jiantianba reef complex can be subdivided into four phases. Water depth, illumination, and temperature determine the difference between the heterozoan reef core association and photozoan reef core association, while the different hydrodynamic condition between the wave zone and tidal zone determine the lithologic characteristic between the reef crest and reef-bank association.

4. This study provides detailed reefal architectures. The lithofacies description combined with the microscopic and macroscopic observation contributes to restoring the information of the paleogeographic and paleoceanographic condition. The Jiantianba reef can be used as an analogy object for comparative studies of the development of the reefs during the different geological periods.

Author Contributions: Conceptualization, B.C.; Methodology X.X. and B.C.; writing-original draft preparation, B.C.; Investigation, F.W.; Z.M. and B.C.; Supervision, X.X. and I.S.A.-A.; Writing-review and editing, I.S.A.-A. \& X.X. 
Funding: This research was funded by National Science and Technology Major Project, grant number 2017ZX05026-005-002 and National Natural Science Foundation of China, grant number 91528301.

Acknowledgments: The first author thanks award of the China Scholarship Council for one year's study at the University of Windsor, Canada. I.S.A.-A. acknowledges the continuous support from NSERC. The first author thanks Fei Shang; Laiyuan Guo; Shuai Zhao; Ya Gao from the China University of Geosciences (Wuhan) for helping with the field work. The first author thanks Pan Zhang from the China University of Geosciences (Wuhan) for discussion.

Conflicts of Interest: The authors declare no conflict of interest.

\section{References}

1. Riding, R. Structure and composition of organic reefs and carbonate mud mounds: Concepts and categories. Earth-Sci. Rev. 2002, 58, 163-231. [CrossRef]

2. Insalaco, E. The descriptive nomenclature and classification of growth fabrics in fossil scleractinian reefs. Sediment. Geol. 1998, 118, 159-186. [CrossRef]

3. James, N.P. The cool-water carbonate depositional realm. Cool-Water Carbonate 1997, 56. [CrossRef]

4. Reid, C.M. Faunal turnover and changing oceanography: Late Palaeozoic warm-to-cool water carbonates, Sverdrup Basin, Canadian Arctic Archipelago. Palaeogeogr. Palaeoclimatol. Palaeoecol. 2007, 249, 128-159. [CrossRef]

5. Westphal, H.; Halfar, J.; Freiwald, A. Heterozoan carbonates in subtropical to tropical settings in the present and past. Int. J. Earth Sci. 2010, 99, 153-169. [CrossRef]

6. Halfar, J.; Godinez-Orta, L.; Mutti, M.; Valdez-Holguín, J.E.; Borges, J.M. Nutrient and temperature controls on modern carbonate production: An example from the Gulf of California, Mexico. Geology 2004, 32, $213-216$. [CrossRef]

7. Mutti, M.; Hallock, P. Carbonate systems along nutrient and temperature gradients: Some sedimentological and geochemical constraints. Int. J. Earth Sci. 2003, 92, 465-475. [CrossRef]

8. Hong, J.; Choh, S.J.; Lee, D.J. Untangling intricate microbial-sponge frameworks: The contributions of sponges to Early Ordovician reefs. Sediment. Geol. 2015, 318, 75-84. [CrossRef]

9. Richter, D.K.; Neuser, R.D.; Schreuer, J.; Gies, H.; Immenhauser, A. Radiaxial-fibrous calcites: A new look at an old problem. Sediment. Geol. 2011, 239, 23-36. [CrossRef]

10. Reijmer, J.J.G.; Bauch, T.; Schäfer, P. Carbonate facies patterns in surface sediments of upwelling and non-upwelling shelf environments (Panama, East Pacific). Sedimentology 2012, 59, 32-56. [CrossRef]

11. He, Y.B.; Luo, J.X.; Wen, Z.; Liu, M.; Wang, Y. Lithofacies palaeogeography of the Upper Permian Changxing Stage in the Middle and Upper Yangtze Region, China. J. Palaeogeogr. 2013, 2, 139-162.

12. Fan, J.S.; Zhang, W. Sphinctozoana from Late Permian Reefs of Uchuan, West Hubei, China. Facies 1985, 13, $1-43$.

13. Rigby, J.K.; Fan, J.S.; Zhang, W. Sphinctozoan sponges from the Permian reefs of South China. J. Paleontol. 1989, 63, 404-439. [CrossRef]

14. Senowbari-Daryan, B.; Hamedani, A.; Rashidi, K. Sponges from the Permian of Hambast Mountains, south of Abadeh, central Iran. Facies 2007, 53, 575-614. [CrossRef]

15. Nakazawa, T.; Igawa, T.; Ueno, K.; Fujikawa, M. Middle Permian sponge-microencruster reefal facies in the mid-Panthalassan Akiyoshi atoll carbonates: Observations on a limestone slab. Facies 2015, 61, 15. [CrossRef]

16. Fan, J.S. The upper Permian reefs in Lichuan district, west Hubei. Chin. J. Geol. 1982, 274-282, (In Chinese, with English abstract).

17. Guo, L.; Riding, R. Microbial micritic carbonates in uppermost Permian reefs, Sichuan Basin, southern China: Some similarities with Recent travertines. Sedimentology 1992, 39, 37-53. [CrossRef]

18. Liu, H.; Rigby, J.K. Diagenesis of the Upper Permian Jiantianba Reef, West Hubei, China. J. Sediment. Res. 1992, 62. [CrossRef]

19. Hu, M.Y.; Wei, H.; Qiu, X.S.; Zhao, E.Z. Reef composition and their forming models of Changxing Formation in Jiantianba Section of Lichuan, Western Hubei. Acta Sedimentol. Sin. 2012, 30, 33-42.

20. Ma, Y.; Guo, X.; Guo, T.; Huang, R.; Cai, X.; Li, G. The Puguang gas field: New giant discovery in the mature Sichuan Basin, southwest China. AAPG Bull. 2007, 91, 627-643. [CrossRef] 
21. Sremac, J.; Jurkovšek, B.; Aljinović, D.; Kolar-Jurkovšek, T. Equatorial Palaeotethys as the last sanctuary for late Permian metazoan reef-builders: New evidence from the Bellerophon Formation of Slovenia. Palaeogeogr. Palaeoclimatol. Palaeoecol. 2016, 454, 91-100. [CrossRef]

22. Aubrecht, R.; Schlögl, J.; Krobicki, M.; Wierzbowski, H.; Matyja, B.A.; Wierzbowski, A. Middle Jurassic stromatactis mud-mounds in the Pieniny Klippen Belt (Carpathians)—A possible clue to the origin of stromatactis. Sediment. Geol. 2009, 213, 97-112. [CrossRef]

23. Bathurst, R.G.C. Genesis of stromatactis cavities between submarine crusts in Palaeozoic carbonate mud buildups. J. Geol. Soc. 1982, 139, 165-181. [CrossRef]

24. Bourque, P.A.; Raymond, L. Diagenetic alteration of early marine cements of Upper Silurian stromatactis. Sedimentology 1994, 41, 255-269. [CrossRef]

25. Hu, M.Y. Platform edge reef and bank structure and depositional model of Changxing formation in Panlongdong section, Xuanhan, northeastern Sichuan. J. Earth Sci. 2012, 23, 431-441. [CrossRef]

26. Blomeier, D.; Dustira, A.; Forke, H.; Scheibner, C. Environmental change in the Early Permian of NE Svalbard: From a warm-water carbonate platform (Gipshuken Formation) to a temperate, mixed siliciclastic-carbonate ramp (Kapp Starostin Formation). Facies 2011, 57, 493-523. [CrossRef]

27. Boulvain, F. Frasnian Carbonate Mounds from Belgium: Sedimentology and Palaeoceanography; Geological Society: London, UK, 2007; pp. 125-142.

28. Álvaro, J.J. (Ed.) Palaeozoic Reefs and Bioaccumulations: Climatic and Evolutionary Controls; Geological Society of London: London, UK, 2007.

29. Kendall, C.G.S.C.; Schlager, W. Carbonates and relative changes in sea level. Mar. Geol. 1981, 44, 181-212. [CrossRef]

30. Goldhammer, R.K.; Dunn, P.A.; Hardie, L.A. Depositional cycles, composite sea-level changes, cycle stacking patterns, and the hierarchy of stratigraphic forcing: Examples from Alpine Triassic platform carbonates. Geol. Soc. Am. Bull. 1990, 102, 535-562. [CrossRef]

31. Wilson, M.E.J. Equatorial carbonates: An earth systems approach. Sedimentology 2012, 59, 1-31. [CrossRef]

32. Pomar, L. Reef geometries, erosion surfaces and high-frequency sea-level changes, upper Miocene Reef Complex, Mallorca, Spain. Sedimentology 1991, 38, 243-269. [CrossRef]

33. Shen, J.W.; Kawamura, T.; Yang, W.R. Upper Permian coral reef and colonial rugose corals in northwest Hunan, South China. Facies 1998, 39, 35-65.

34. Wu, L.; Jiao, Y.; Rong, H.; Wang, R.; Li, R. Reef types and sedimentation characteristics of Changxing formation in Manyue-Honghua Section of Kaixian, Northeastern Sichuan Basin. J. Earth Sci. 2012, 23, 490-505. [CrossRef]

35. Shen, J.; Xu, H. Microbial carbonates as contributors to Upper Permian (Guadalupian-Lopingian) biostromes and reefs in carbonate platform margin setting, Ziyun County, South China. Palaeogeogr. Palaeoclimatol. Palaeoecol. 2005, 218, 217-238. [CrossRef]

36. Zhao, W.; Xu, C.; Wang, T.; Wang, H.; Wang, Z.; Bian, C.; Li, X. Comparative study of gas accumulations in the Permian Changxing reefs and Triassic Feixianguan oolitic reservoirs between Longgang and Luojiazhai-Puguang in the Sichuan Basin. Chin. Sci. Bull. 2011, 56, 3310-3320. [CrossRef]

37. Chen, L.; Lu, Y.; Fu, X.; Xing, F.; Wang, C.; Luo, C. Oolitic shoal complexes characterization of the Lower Triassic Feixianguan Formation in the Yuanba Gas Field, Northeast Sichuan Basin, China. Mar. Pet. Geol. 2017, 83, 35-49. [CrossRef]

38. Guo, C.; Li, G.; Wei, H.; Xia, F.; Xie, F. Stratigraphic architecture and platform evolution of the Changxing Formation (Upper Permian) in the Yuanba Gas Field, northeastern Sichuan Basin, China. Arabian J. Geosci. 2016, 9, 359. [CrossRef]

39. Chen, L.; Lu, Y.C.; Guo, T.L.; Deng, L.S. Growth characteristics of Changhsingian (Late Permian) carbonate platform margin reef complexes in Yuanba Gas Field, northeastern Sichuan Basin, China. Geol. J. 2012, 47, 524-536. [CrossRef]

(c) 2018 by the authors. Licensee MDPI, Basel, Switzerland. This article is an open access article distributed under the terms and conditions of the Creative Commons Attribution (CC BY) license (http:/ / creativecommons.org/licenses/by/4.0/). 